\title{
Functional oncogene signatures guide rationally designed combination therapies to synergistically induce breast cancer cell death
}

\author{
Stephen T. Guest ${ }^{1}$, Zachary R. Kratche ${ }^{1}$, Jonathan C. Irish ${ }^{1}$, Robert C. Wilson ${ }^{1}$, \\ Ramsi Haddad ${ }^{1}$, Joe W. Gray ${ }^{3,4}$, Elizabeth Garrett-Mayer ${ }^{2}$, Stephen P. Ethier ${ }^{1}$ \\ ${ }^{1}$ Department of Pathology and Laboratory Medicine, Hollings Cancer Center, Medical University of South Carolina, Charleston, \\ South Carolina, USA \\ ${ }^{2}$ Department of Public Health Science, Medical University of South Carolina, Charleston, South Carolina, USA \\ ${ }^{3}$ Department of Biomedical Engineering, Oregon Health and Sciences University, Portland, Oregon, USA \\ ${ }^{4}$ Knight Cancer Institute, Oregon Health and Sciences University, Portland, Oregon, USA \\ Correspondence to: Stephen T. Guest, email: guests@musc.edu
}

Keywords: breast cancer, functional genomics, BCL2L1, FGFR, AKT

Received: January 28, 2016

Accepted: April 10, 2016

Published: May 02, 2016

\section{ABSTRACT}

A critical first step in the personalized approach to cancer treatment is the identification of activated oncogenes that drive each tumor. The Identification of driver oncogenes on a patient-by-patient basis is complicated by the complexity of the cancer genome and the fact that a particular genetic alteration may serve as a driver event only in a subset of tumors that harbor it. In this study, we set out to identify the complete set of functional oncogenes in a small panel of breast cancer cell lines. The cell lines in this panel were chosen because they each contain a known receptor tyrosine kinase (RTK) oncogene. To identify additional drivers, we integrated functional genetic screens with copy number and mutation analysis, and cancer genome knowledge databases. The resulting functional oncogene signatures were able to predict responsiveness of cell lines to targeted inhibitors. However, as single agents, these drugs had little effect on clonogenic potential. By contrast, treatment with drug combinations that targeted multiple oncogenes in the signatures, even at very low doses, resulted in the induction of apoptosis and striking synergistic effects on clonogenicity. In particular, targeting a driver oncogene that mediates AKT phosphorylation in combination with targeting the anti-apoptotic BCL2L1 protein had profound effects on cell viability. Importantly, because the synergistic induction of cell death was achieved using low levels of each individual drug, it suggests that a therapeutic strategy based on this approach could avoid the toxicities that have been associated with the combined use of multipletargeted agents.

\section{INTRODUCTION}

Cancer is a genomic disease that results from the progressive acquisition of dominant genomic alterations in driving oncogenes and recessive mutations in tumor suppressor genes. Laboratory and clinical investigations have demonstrated that human cancer cells become dependent on the activity of driver oncogenes for the expression of transformed phenotypes and for their survival. This idea, known as oncogene addiction $[1,2]$, has become a cornerstone for the development of targeted cancer therapeutics because it results in cells that are dependent on the oncogene for survival, and increases the sensitivity of the addicted cells to oncogene-targeted drugs which provides the therapeutic index needed for cancer cell specific effects on viability [2]. There is ample evidence in support of this hypothesis from laboratory studies, but the most compelling evidence comes from clinical studies involving targeted agents such as imatinib [3-6], trastuzumab [7-9], erlotinib [10], and vemurafinib 
[11] which have yielded dramatic clinical responses when the cognate driving oncogene is present in the treated cancer cells. However, it has also been repeatedly observed that clinical responses to these targeted agents, even when they are dramatic, are transient and followed by recurrences of the disease. It is increasingly clear that multiple driver oncogenes become activated during the evolution of most solid tumors, resulting in cancer cells that harbor complex oncogene signatures, and we hypothesize that these complex oncogene signatures help to explain the transient response of cancer cells to attack on a single oncogene.

In this study, we set out to identify the complete set of driver oncogenes that are functioning in a small panel of breast cancer cell lines. We refer to this complete set of oncogenes as the functional oncogene signature of the cell line. In order to determine functional oncogene signatures for each cell line, we combined results of genome-wide functional genetic screens with copy number analysis, exome sequencing data, and cancer knowledge databases. Elucidation of functional oncogene signatures allowed us to identify novel driver oncogenes in each cell line, and accurately predicted the responsiveness and sensitivity of the cell lines to targeted drugs. The oncogene signatures also allowed us to identify drug combinations that resulted in striking, synergistic effects on breast cancer cell viability. Our results specifically support a therapeutic strategy targeting a driver oncogene that mediates AKT phosphorylation in combination with targeting the antiapoptotic BCL2L1 protein when it is part of the functional oncogene signature. The synergy observed using this approach suggests that an effective response can be achieved using low levels of each individual drug and thereby avoid toxicities that have hampered the use of combination therapies in the clinic.

\section{RESULTS}

\section{Elucidation of functional oncogene signatures in a small panel of breast cancer cell lines}

A primary goal of the experiments reported here was to elucidate complete functional oncogene signatures for a small panel of SUM breast cancer cell lines [12], each of which is known to harbor a driving RTK oncogene activated by amplification (SUM-52/FGFR2, SUM-185/ FGFR3, SUM-225/HER2, SUM-190/HER2) [13, 14]. In order to elucidate the functional oncogene signature for each of these cell lines, we first determined gene copy number status in each cell line because gene amplification is a common mechanism of oncogene activation. Array comparative genomic hybridization analysis revealed that each cell line harbors hundreds of genes that are copy number amplified (Supplementary Tables 1-4). This large number of amplified genes is a common feature of breast cancers [15]; however, only a small number of the amplified genes are likely to be functioning as activated driver oncogenes, with the remaining alterations being likely passenger genes.

To determine which of the amplified genes in each cell line play a functional role in driving cell growth and viability, and are therefore likely activated driver oncogenes, we performed a genome-scale shRNA growth and viability screen on each cell line. For each screen, cells were transduced with a library of 82,000 lentiviral vectors expressing shRNAs targeting 15,377 cellular genes, with a minimum of four shRNAs per gene. Cells were harvested at day 3 after selection and again after approximately 5-7 population doublings. The abundance of shRNAs at both time points was determined by next-generation sequencing of PCR-amplified shRNAassociated barcodes. Fold depletion values were used to calculate a gene level score for each gene and gene level scores were then used to identify significantly depleted genes (See Methods and $[16,17]$ ) (Supplementary Tables $5-8)$.

Integrating the data from the shRNA screens with the gene copy number data allowed us to identify the copy number amplified genes that were also essential for growth and viability of the cells. Tables 1-4 show the results of this analysis for each of the four cell lines. This analysis dramatically reduced the number of candidate oncogenes in each of the cell lines from hundreds, to less than 50 . Interestingly, we observed that in all four cell lines, the majority of amplicons harbored multiple genes that were hits in the screen. This result is consistent with the hypothesis that amplicons are selected for during cancer evolution because they harbor multiple genes important to the growth and survival of the cancer cells.

Next, to define functional oncogene signatures with the greatest relevance to human cancer generally, we filtered the list of amplified genes that were hits in the shRNA screen using the Genomic Identification of Significant Targets in Cancer (GISTIC) database (http:// www.broadinstitute.org/tcga/home) $[18,19]$ and the cancer Gene Ranker database (http://cbio.mskcc.org/ tcga-generanker/batch.jsp) (Tables 1-4). This approach allowed us to focus on candidate oncogenes that are located in regions of recurrent amplification in primary human cancers as defined by GISTIC, and are considered to be important cancer genes as determined by Gene Ranker (Gene Ranker score $\geq 1$ ). This analysis again significantly reduced the number of candidate oncogenes in each of the cell lines (Table 5).

Point mutations are another mechanism by which oncogenes can become activated. To include oncogenes activated by point mutation in the functional oncogene signatures, we integrated the shRNA screen data with exome sequencing data. Before integrating the exome sequencing data with the shRNA screen data, the exome sequencing data was first filtered using the Catalog of Somatically Mutated Genes in Cancer (COSMIC; cancer. 
Table 1: SUM-52 copy number amplified genes that are hits in the shRNA screen

\begin{tabular}{|c|c|c|c|}
\hline Gene symbol & Locus & Gene ranker score ${ }^{1}$ & GISTIC $^{2}$ \\
\hline CDK6 & $7 \mathrm{q} 21$ & 7 & Yes \\
\hline TFR2 & $7 q 22$ & 1 & Yes \\
\hline CPSF4 & $7 \mathrm{q} 22.2$ & 1 & Yes \\
\hline BET1 & $7 \mathrm{q} 21.1$ & 0.5 & Yes \\
\hline KAT6A & $8 \mathrm{p} 11$ & 3.5 & Yes \\
\hline STAR & $8 \mathrm{p} 11.2$ & 1 & Yes \\
\hline CPSF1 & $8 \mathrm{q} 24.2$ & 0 & Yes \\
\hline MAF1 & $8 \mathrm{q} 24.3$ & 0 & Yes \\
\hline PUF60 & $8 \mathrm{q} 24.3$ & 0 & Yes \\
\hline DUSP26 & $8 \mathrm{p} 12$ & 3.5 & No \\
\hline NRG1 & $8 \mathrm{p} 12$ & 0 & No \\
\hline FGFR2 & $10 \mathrm{q} 26$ & 6.25 & Yes \\
\hline RPS3 & $11 \mathrm{q} 13.3$ & 1 & Yes \\
\hline CAPN5 & $11 \mathrm{q} 14$ & 0 & Yes \\
\hline TBK1 & $12 \mathrm{q} 14.1$ & 2.5 & Yes \\
\hline IL22 & $12 q 15$ & 0 & Yes \\
\hline KRR1 & $12 \mathrm{q} 21.2$ & 1 & No \\
\hline SLTM & $15 \mathrm{q} 22.1$ & 0 & No \\
\hline DDX5 & $17 \mathrm{q} 21$ & 1.5 & Yes \\
\hline CD79B & $17 \mathrm{q} 23$ & 1 & Yes \\
\hline TLK2 & $17 \mathrm{q} 23.2$ & 1 & Yes \\
\hline TBX2 & $17 \mathrm{q} 23.2$ & 0.5 & Yes \\
\hline PTPRH & $19 \mathrm{q} 13.4$ & 2 & Yes \\
\hline NDUFB7 & $19 q 13.12$ & 1 & Yes \\
\hline TNNT1 & 19q13.4 & 0 & Yes \\
\hline PLAUR & $19 \mathrm{q} 13$ & 1.75 & No \\
\hline PRPF31 & $19 q 13$ & 1.5 & No \\
\hline RELB & $19 \mathrm{q} 13.3$ & 1.5 & No \\
\hline RUVBL2 & $19 q 13.3$ & 1.5 & No \\
\hline SNRPD2 & $19 \mathrm{q} 13.2$ & 0.5 & No \\
\hline RPS9 & $19 \mathrm{q} 13.4$ & 0 & No \\
\hline GNAS & $20 \mathrm{q} 13.3$ & 5.5 & Yes \\
\hline PTPN1 & $20 \mathrm{q} 13.1$ & 3.5 & Yes \\
\hline NTSR1 & $20 \mathrm{q} 13$ & 2 & Yes \\
\hline NELFCD & $20 q 13.33$ & 1 & Yes \\
\hline TFAP2C & 20q13.2 & 0.5 & Yes \\
\hline CTSZ & $20 q 13.33$ & 0.5 & Yes \\
\hline PRPF6 & $20 \mathrm{q} 13.33$ & 0 & Yes \\
\hline PSMA7 & $20 \mathrm{q} 13.33$ & 0 & Yes \\
\hline RPS21 & $20 \mathrm{q} 13.33$ & 0 & Yes \\
\hline CHRNA4 & $20 \mathrm{q} 13.33$ & 0 & Yes \\
\hline
\end{tabular}




\begin{tabular}{|c|c|c|c|}
\hline KCNB1 & $20 \mathrm{q} 13.2$ & 2.5 & No \\
\hline PIGA & Xp22.1 & 1 & No \\
\hline PIR & Xp22.2 & 0.5 & No \\
\hline
\end{tabular}

1-Gene Ranker scores are from http://cbio.mskcc.org/tcga-generanker/index.jsp.

2-Indicates whether or not the gene is located in a region of recurrent amplification as determined by GISTIC analysis of 10844 samples in the TCGA database (TCGA database version 2015-06-01 stddata).

sanger.ac.uk) [20] database to identify only the variants that have been shown to be recurrent somatic mutations in human cancer. In each cell line, this reduced the number of genes harboring mutations to less than 30 . In the SUM-190 and SUM-185 cell lines, merging the mutated gene lists with the shRNA screen hits identified a single gene, the well-characterized driver oncogene PIK3CA [21-24]. Both cell lines harbor the H1047R substitution mutation, which is one of the most commonly reported activating mutations for PIK3CA in breast cancer [21, $25,26]$. The SUM-52 and SUM-225 cell lines also each contained a single point mutated gene that was a hit in the shRNA screen although in both cases the identified mutation was only rarely observed in primary cancers. Combining this analysis of point mutated genes with the analysis of copy number amplified genes resulted in a final functional oncogene signature for each cell line (Table 5).

\section{Oncogene signatures predict sensitivity to molecularly targeted drugs}

We hypothesized that the identified functional oncogene signatures would be able to accurately predict sensitivity to targeted therapies. To test this hypothesis, we identified genes in each functional oncogene signature that have an available targeted inhibitor. Six genes were identified overall (BCL2L1, CDK6, PIK3CA, FGFR2, FGFR3, and HER2), with each cell line signature containing at least one druggable driver oncogene. The BCL2L1 gene, which is part of the SUM-185 functional oncogene signature, was of particular interest because a role for amplified BCL2L1 as a driver oncogene in breast cancer has not been previously characterized. We therefore tested the cell line panel for sensitivity to the BCL2L1-targeted drug Navitoclax [27]. As predicted from the functional oncogene signature, SUM-185 cells were highly sensitive to this drug and were the most sensitive cell line in our panel with an IC50 in a growth assay of approximately $0.1 \mu \mathrm{M}$ (Figure 1A). Because BCL2L1 has not been previously characterized as a driver oncogene in breast cancer, we used the TCGA cell line database (http://www.cbioportal.org/) to identify an additional breast cancer cell line, HCC38, which also harbors a focal amplification of BCL2L1. Interestingly, treatment of HCC38 cells with Navitoclax revealed a high level of sensitivity that was equivalent to that of SUM185 cells (Figure 1B). Querying the TCGA database for BCL2L1 amplification in primary breast tumors revealed that 430/1105 (39\%) samples harbor BCL2L1 copy number gain and 23/1105 (2\%) harbor a high-level focal amplification as determined by GISTIC (Figure 1C). Additionally, there is a trend towards increased expression with increasing levels of gene copy number which is a characteristic of driver oncogenes that are activated by amplification (Figure 1C). Taken together, these results suggest that functional oncogene signatures can accurately predict drug sensitivity and specifically support a role for BCL2L1 as a novel driver oncogene and potential therapeutic target in a subset of breast cancers.

In order to further test the ability of the functional oncogene signatures to predict sensitivity to targeted therapies, we examined the response of our cell line panel to inhibitors that target each of the remaining druggable driver oncogenes. The SUM-52 and SUM185 cell lines each have FGFR family members in their oncogene signatures and we and others have demonstrated previously the extreme sensitivity of SUM-52 cells to FGFR2 inhibitors [28-30]. Treating the cell line panel with the small molecule FGFR inhibitor, PD173074 [31], showed that SUM-52 and SUM-185 cells were both highly sensitive to this drug with IC50 values $\sim .05 \mathrm{uM}$ (Figure 2A). Thus, for these two cell lines, having an FGFR family member as part of the functional oncogene signature was predictive of sensitivity to the appropriate targeted drug.

The SUM-225 and SUM-190 cell lines were chosen for these studies because they were known to harbor an amplification and overexpression of the HER2 oncogene [14]. Interestingly, whereas HER2 (as well as its neighbor on the amplicon GRB7) was a hit in the SUM225 shRNA screen, HER2 was not a hit in the SUM-190 screen. Examining the sensitivity of the cell line panel to the HER2 inhibitor CP724721 [32] showed that while SUM-52 and SUM-185 cells were unresponsive to this drug, SUM-225 cells were highly sensitive (Figure 2B). By contrast, while SUM-190 cells were responsive to this inhibitor, the IC50 value was 10 -fold greater than for SUM-225 cells. This result helps to explain why HER2 was not a hit in the shRNA screen in SUM-190 cells, as these cells are relatively resistant to targeting HER2.

Examining the sensitivity of the cell line panel to the small molecule PIK3CA inhibitor A66 showed that SUM185 cells which harbor an activating PIK3CA mutation were indeed, more than 10-fold more sensitive to A66 than any of the other cell lines, including SUM-190 (Figure 2C). The SUM-190 cells exhibited the same sensitivity to this 
Table 2: SUM-185 copy number amplified genes that are hits in the shRNA screen

\begin{tabular}{|c|c|c|c|}
\hline \multicolumn{2}{|c|}{ Gene symbol } & Gene ranker score & GISTIC $^{\mathbf{1}}$ \\
\hline FGFR3 & $4 \mathrm{p} 16.3 \mathrm{~b}$ & 8.5 & Yes \\
\hline CTBP1 & $4 \mathrm{p} 16.3 \mathrm{c}$ & 2.5 & Yes \\
\hline ANKRD17 & $4 \mathrm{q} 13.3 \mathrm{~d}$ & 1 & Yes \\
\hline IDUA & $4 \mathrm{p} 16.3 \mathrm{c}$ & 2 & No \\
\hline GPT2 & $16 \mathrm{q} 11.2 \mathrm{i}$ & 1 & No \\
\hline ISYNA1 & $19 \mathrm{p} 13.11 \mathrm{c}$ & 1 & Yes \\
\hline HSPBP1 & $19 \mathrm{q} 13.42 \mathrm{~b}$ & 0 & Yes \\
\hline NDUFA13 & $19 \mathrm{p} 13.11 \mathrm{a}$ & 2.25 & Yes \\
\hline BCL2L1 & $20 \mathrm{q} 11.21 \mathrm{~b}$ & 3.5 & Yes \\
\hline ID1 & $20 \mathrm{q} 11.21 \mathrm{~b}$ & 2.5 & Yes \\
\hline POFUT1 & $20 \mathrm{q} 11.21 \mathrm{~b}$ & 2.25 & Yes \\
\hline COX412 & $20 \mathrm{q} 11.21 \mathrm{~b}$ & 1 & No \\
\hline ACSS1 & $20 \mathrm{p} 11.21 \mathrm{a}$ & 2 & No \\
\hline SSTR4 & $20 \mathrm{p} 11.21 \mathrm{c}$ & 0 & No \\
\hline NKX2-2 & $20 \mathrm{p} 11.22 \mathrm{~b}$ & 0 & \multicolumn{2}{c|}{} \\
\hline
\end{tabular}

1-Gene Ranker scores are from http://cbio.mskcc.org/tcga-generanker/index.jsp.

2-Indicates whether or not the gene is located in a region of recurrent amplification as determined by GISTIC analysis of 10844 samples in the TCGA database (TCGA database version 2015-06-01 stddata).
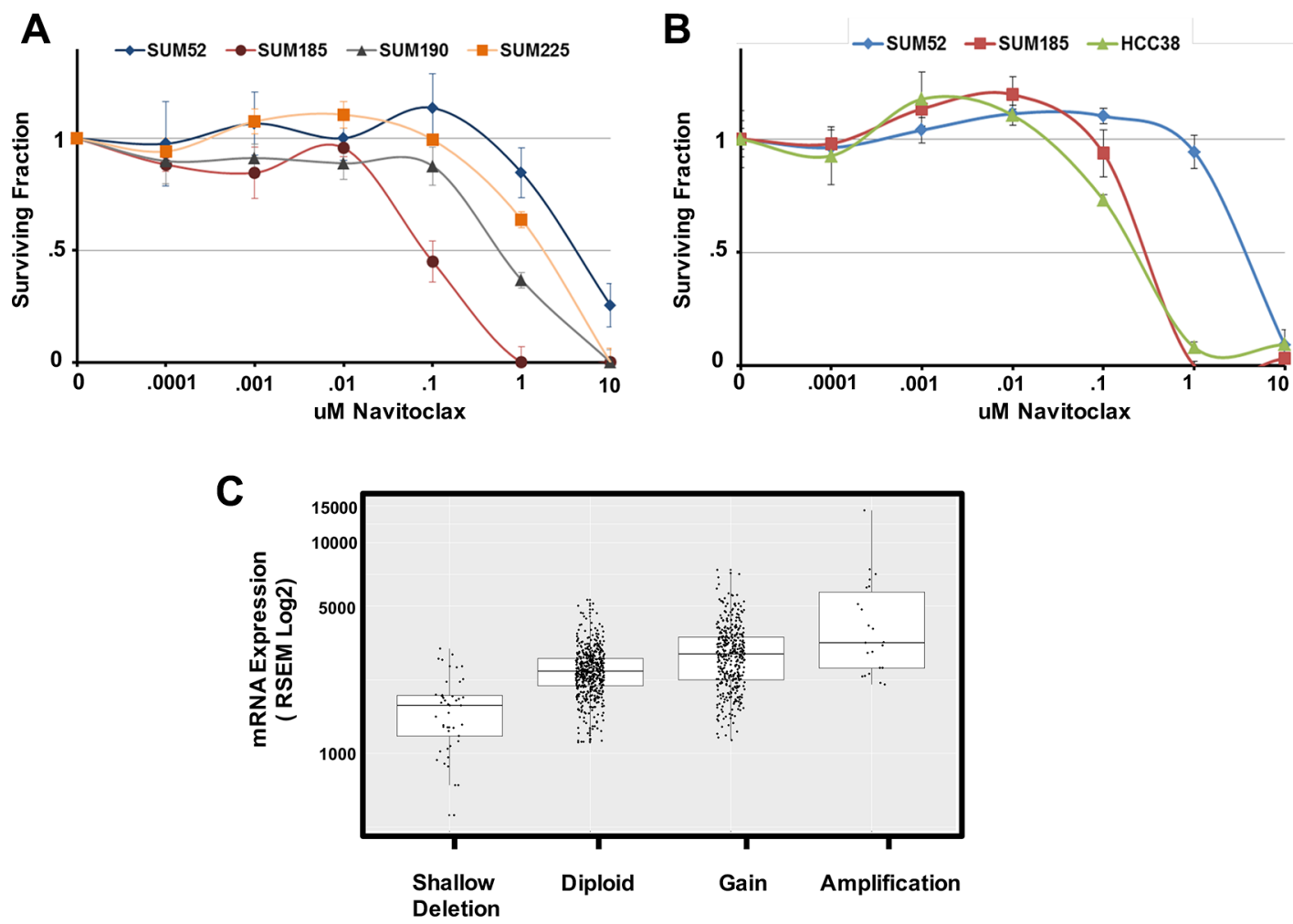

Figure 1: Oncogene signatures predict sensitivity to the BCL211 targeted drug Navitoclax. (A) Cell number for each cell line in the panel expressed as fraction of control. Cells were treated with the indicated concentrations of Navitoclax for 96 hours. (B) Cell number for the BCL2L1-amplifeid breast cancer cell line HCC38 in comparison to SUM-185 and SUM-52 cells following exposure to the indicated concentrations of Navitoclax for 96 hours. (C) Boxplot of BCL2L1 mRNA expression levels for the 1105 primary breast tumors in the TCGA database. Tumors were grouped based on TCGA analysis of BCL2L1 gene copy number. Data for individual tumors is shown as data points over boxplots. 
Table 3: SUM-190 copy number amplified genes that are hits in the shRNA screen

\begin{tabular}{|c|c|c|c|}
\hline Gene symbol & Locus & Gene ranker score ${ }^{1}$ & GISTIC $^{2}$ \\
\hline CXCL5 & $4 q 13.3 d$ & 0 & Yes \\
\hline EPHA5 & $4 q 13.1 f$ & 3.25 & No \\
\hline STK3 & $8 \mathrm{q} 22.2 \mathrm{a}$ & 1 & Yes \\
\hline C8ORF59 & $8 \mathrm{q} 21.2 \mathrm{~b}$ & 0 & Yes \\
\hline PLEKHF2 & $8 \mathrm{q} 22.1 \mathrm{c}$ & 0 & Yes \\
\hline RPL30 & $8 \mathrm{q} 22.2 \mathrm{a}$ & 0 & Yes \\
\hline SPAG1 & $8 \mathrm{q} 22.2 \mathrm{~b}$ & 0 & Yes \\
\hline LRP12 & $8 \mathrm{q} 22.3 \mathrm{~d}$ & 0 & Yes \\
\hline EMC2 & $8 \mathrm{q} 23.1 \mathrm{~d}$ & 0 & Yes \\
\hline RTN4RL2 & $11 \mathrm{q} 12.1 \mathrm{a}$ & 0 & No \\
\hline UBN1 & $16 \mathrm{p} 13.3 \mathrm{~b}$ & 0 & No \\
\hline NR1D1 & $17 \mathrm{q} 21.1 \mathrm{c}$ & 1 & Yes \\
\hline FNDC8 & $17 q 12 a$ & 0 & No \\
\hline RPL27 & $17 \mathrm{q} 21.31 \mathrm{a}$ & 0 & No \\
\hline TMEM106A & $17 \mathrm{q} 21.31 \mathrm{~b}$ & 0 & No \\
\hline MTCP1 & Xq28h & 2 & Yes \\
\hline
\end{tabular}

1-Gene Ranker scores are from http://cbio.mskcc.org/tcga-generanker/index.jsp.

2-Indicates whether or not the gene is located in a region of recurrent amplification as determined by GISTIC analysis of 10844 samples in the TCGA database (TCGA database version 2015-06-01 stddata).

drug as SUM-52 and SUM-225 cells even though they also harbor an activating PIK3CA mutation. It is possible that the presence of PIK3CA mutations in the context of HER2 amplifications could result in reduced sensitivity to either drug target alone by compensating for each other in the presence of a single agent [33].

Finally, since CDK6 was part of the functional oncogene signature in SUM-52 cells, we examined the cell line panel for sensitivity to the CDK4/6 inhibitor palbociclib [34]. All four cell lines displayed similar sensitivity to palbociclib thus, in this case, CDK6 being a functional oncogene did not predict enhanced sensitivity to palbociclib (Figure 2D). Looking only at shRNA screen data, CDK6 was a hit in both the SUM-52 and SUM-185 cell lines but not in the SUM-190 or SUM-225 cell lines. Therefore, the shRNA screen data alone was also not predictive of response to palbociclib.

\section{Oncogene signatures guide rational combination therapies that synergistically induce cancer cell death}

Beyond predicting sensitivity to individual targeted agents, elucidation of functional oncogene signatures offers an opportunity to correctly predict effective targeted drug combinations. Combining multiple targeted therapies has been proposed as an approach for improving patient response rates and also for serving as a barrier to the development of resistance [35-42]. We therefore performed experiments to determine if targeting multiple oncogenes in a signature would yield synergistic interactions specific to an individual cell line. For these experiments we performed clonogenic survival assays (colony-forming assays) to determine if drug combinations could have irreversible effects on the proliferative capacity of the cells. We have previously demonstrated that for SUM-52 cells, 72 hour exposure to the FGFR inhibitor PD173074, while resulting in complete inhibition of proliferation, had only a small effect on colony-forming ability once the drug was removed [17], indicating that the effects of this drug on growth were reversible. We have reported similar results with other small molecule kinase inhibitors in other breast cancer cell lines [43]. Thus, the experiments reported here were aimed at identifying drug combinations that would result in irreversible effects on growth and clonogenicity.

The SUM-185 cell line functional oncogene signature suggested an obvious combination strategy involving small molecule inhibitors that target each of three oncogenes in the signature, FGFR3, PIK3CA and BCL2L1. We therefore performed a clonogenic survival assay in which SUM-185 cells were treated with IC50 concentrations of the FGFR, PI3' $\mathrm{K}$, or BCL2L1 inhibitors alone, or the two- and three-drug combinations. As expected from previous experiments, we observed that treatment with individual drugs resulted in little or no effect on colony forming ability (Figure 3A and 3B). In stark contrast, combined treatment of SUM-185 cells 
Table 4: SUM-225 copy number amplified genes that are hits in the shRNA screen

\begin{tabular}{|c|c|c|c|}
\hline Gene symbol & Locus & Gene ranker score $^{1}$ & GISTIC $^{2}$ \\
\hline CDKL2 & $4 \mathrm{q} 21.1 \mathrm{a}$ & 1.5 & Yes \\
\hline CXCL3 & $4 q 13.3 d$ & 0 & Yes \\
\hline CYP51A1 & $7 \mathrm{q} 21.2 \mathrm{a}$ & 2 & Yes \\
\hline ANKIB1 & $7 \mathrm{q} 21.2 \mathrm{a}$ & 1 & Yes \\
\hline RAD21 & $8 \mathrm{q} 24.11 \mathrm{a}$ & 2.5 & Yes \\
\hline GPT & $8 \mathrm{q} 24.3 \mathrm{~h}$ & 2.25 & Yes \\
\hline ST3GAL1 & $8 \mathrm{q} 24.22 \mathrm{c}$ & 2 & Yes \\
\hline CYP11B1 & $8 \mathrm{q} 24.3 \mathrm{f}$ & 2 & Yes \\
\hline HSF1 & $8 \mathrm{q} 24.3 \mathrm{~g}$ & 1.25 & Yes \\
\hline HNF4G & $8 \mathrm{q} 21.11 \mathrm{c}$ & 1 & Yes \\
\hline TAF2 & $8 \mathrm{q} 24.12 \mathrm{~b}$ & 1 & Yes \\
\hline CCNE2 & $8 \mathrm{q} 22.1 \mathrm{c}$ & 0 & Yes \\
\hline RPL30 & $8 \mathrm{q} 22.2 \mathrm{a}$ & 0 & Yes \\
\hline EIF3E & $8 \mathrm{q} 23.1 \mathrm{c}$ & 0 & Yes \\
\hline ENY2 & $8 \mathrm{q} 23.1 \mathrm{~d}$ & 0 & Yes \\
\hline EIF3H & $8 \mathrm{q} 24.11 \mathrm{a}$ & 0 & Yes \\
\hline MED30 & $8 \mathrm{q} 24.11 \mathrm{~b}$ & 0 & Yes \\
\hline WISP1 & $8 \mathrm{q} 24.22 \mathrm{c}$ & 0 & Yes \\
\hline TSNARE1 & $8 \mathrm{q} 24.3 \mathrm{e}$ & 0 & Yes \\
\hline MAF1 & $8 \mathrm{q} 24.3 \mathrm{~g}$ & 0 & Yes \\
\hline BOP1 & $8 \mathrm{q} 24.3 \mathrm{~g}$ & 0 & Yes \\
\hline PUF60 & $8 \mathrm{q} 24.3 \mathrm{~g}$ & 0 & Yes \\
\hline ZNF707 & $8 \mathrm{q} 24.3 \mathrm{~g}$ & 0 & Yes \\
\hline VPS28 & $8 \mathrm{q} 24.3 \mathrm{~h}$ & 0 & Yes \\
\hline RPL8 & $8 \mathrm{q} 24.3 \mathrm{~h}$ & 0 & Yes \\
\hline DNM1L & $12 \mathrm{p} 11.21 \mathrm{a}$ & 1 & Yes \\
\hline POLR2C & $16 q 13 c$ & 2 & No \\
\hline ATP6V0D1 & $16 \mathrm{q} 22.1 \mathrm{~b}$ & 1 & No \\
\hline CAPNS2 & $16 \mathrm{q} 12.2 \mathrm{c}$ & 0 & No \\
\hline MT1B & $16 q 13 b$ & 0 & No \\
\hline MT1M & $16 q 13 b$ & 0 & No \\
\hline CNOT1 & $16 \mathrm{q} 21 \mathrm{a}$ & 0 & No \\
\hline CTRL & $16 \mathrm{q} 22.1 \mathrm{~b}$ & 0 & No \\
\hline ERBB2 & $17 \mathrm{q} 12 \mathrm{c}$ & 9.25 & Yes \\
\hline GRB7 & $17 q 12 c$ & 1 & Yes \\
\hline
\end{tabular}

1-Gene Ranker scores are from http://cbio.mskcc.org/tcga-generanker/index.jsp.

2-Indicates whether or not the gene is located in a region of recurrent amplification as determined by GISTIC analysis of 10844 samples in the TCGA database (TCGA database version 2015-06-01 stddata).

with IC50 concentrations of the drugs that target the three functional oncogenes resulted in an 800 fold reduction in colony forming (Figure 3A, 3B and 3D). Examining the results of the two-drug combination treatments revealed that combining Navitoclax with either the FGFR or the PI3'kinase inhibitor reduced colony-forming ability by approximately 50 -fold. The similarity of the results for the FGFR and PI3' $\mathrm{K}$ inhibitors in combination with the BCL2L1 inhibitor is in agreement with our recently published results showing that in SUM-185 cells, FGFR3 and PIK3CA both function to drive AKT phosphorylation [44]. These results suggest that, in the 
Table 5: Functional oncogene signatures

\begin{tabular}{|c|c|c|c|c|}
\hline & SUM-52 & SUM-185 & SUM-190 & SUM-225 \\
\hline \multirow{17}{*}{ Amplified } & FGFR2 & FGFR3 & MTCP1 & ERBB2 \\
\hline & CDK6 & BCL2L1 & NR1D1 & RAD21 \\
\hline & GNAS & ID1 & STK3 & GPT \\
\hline & PTPN1 & CTBP1 & & CYP51A1 \\
\hline & КАT6А & POFUT1 & & ST3GAL1 \\
\hline & TBK1 & ISYNA1 & & CYP11B1 \\
\hline & PTPRH & COX4I2 & & CDKL2 \\
\hline & NTSR1 & ANKRD17 & & HSF1 \\
\hline & DDX5 & & & DNM1L \\
\hline & RPS3 & & & GRB7 \\
\hline & CD79B & & & ANKIB1 \\
\hline & TLK2 & & & HNF4G \\
\hline & NDUFB7 & & & TAF2 \\
\hline & NELFCD & & & \\
\hline & TFR2 & & & \\
\hline & CPSF4 & & & \\
\hline & STAR & & & \\
\hline Point Mutated & CDKN2A & PIK3CA & PIK3CA & BIRC6 \\
\hline
\end{tabular}

context of a functional oncogene signature, targeting a driver oncogene that mediates AKT phosphorylation in combination with targeting BCL2L1 has synergistic effects on cell viability even when the drugs are used at low doses. Importantly, treatment of the non-transformed breast epithelial cell line MCF10A with these drug combinations showed no effect on colony-forming ability (Figure 3C and 3D), demonstrating the specificity of this response for transformed cells. Treatment of SUM-185 cells with the three-drug combination induced changes in cell morphology indicative of an apoptotic response (Supplementary Figure S1) and subsequent examination of cell extracts indeed showed potent activation of caspase 3 even at the earliest time point (Figure 3E) suggesting that the observed loss of cell viability was due to induction of apoptosis.

\section{Testing combinatorial treatment strategies including an inhibitor of BCL2L1 in multiple breast cancer cell lines}

Based on the results described above, we hypothesized that inhibition of AKT phosphorylation in combination with BCL2L1 inhibition may induce synergistic cancer cell death in other cancer cell lines. In order to test this hypothesis, we first identified small molecule inhibitors that were capable of inhibiting AKT phosphorylation in each of the cell lines in our panel
(Figure 4). For these experiments, we examined levels of AKT phosphorylation in each cell line following treatment with an inhibitor of the RTK oncogene (PD173074 or CP724721), a pan-PI3'K inhibitor (BKM-120), a PIK3CA specific inhibitor (A66), or an allosteric AKT inhibitor (MK-2206). In SUM-52 cells, treatment with the FGFR inhibitor resulted in effective inhibition of AKT phosphorylation similar to what was observed in SUM-185 cells (Figure 4A and 4B). We therefore tested the effect of the FGFR/BCL2L1 combination therapy in a clonogenic survival assay on SUM-52 cells but because SUM-52 cells were more resistant than SUM-185 cells to the BCL2L1 inhibitor (Figure 1A and 1B), we tested Navitoclax at both $1 \mu \mathrm{M}$ and at the IC50 concentration for SUM-185 cells of $0.1 \mu \mathrm{M}$. The results of this experiment demonstrated that, similar to what we observed for SUM-185 cells, there was a synergistic effect of the FGFR/BCL2L1 drug combination on colony-forming ability (Figure $5 \mathrm{~A}$ and $5 \mathrm{~B}$ ). The synergy was more profound at the higher Navitoclax dose of $1 \mu \mathrm{M}$ however, it should be noted that this level of Navitoclax treatment also reduces colony-forming ability in the non-transformed MCF10A cell line (data not shown).

In SUM-190 cells, treatment with a $1 \mathrm{uM}$ dose of the allosteric AKT inhibitor MK-2206 effectively inhibits AKT phosphorylation (Figure 5C). Combined treatment of SUM-190 cells with 1uM MK-2206 and the BCL2L1 inhibitor did not result in a synergistic effect on colonyforming ability. Similarly, in SUM-225 cells 1uM MK- 
2206 effectively inhibited AKT phosphorylation (Figure 5D) and combining this treatment with the BCL2L1 inhibitor did not result in a synergistic effect. These results indicate that the synergistic response to dual inhibition of BCL2L1 activity and AKT phosphorylation is cancer cell line-specific and can be predicted by the presence of drug targets in the cell line functional oncogene signature.

\section{DISCUSSION}

In this study, we defined functional oncogene signatures for a panel of breast cancer cell lines that share the common feature of each having one known amplified and over-expressed RTK oncogene. To define functional oncogene signatures, we integrated genomic profiling for each cell line with genome-wide functional genetic screens and data from cancer knowledge databases. This analysis identified known as well as novel driver oncogenes for each cell line. Using the functional oncogene signatures, we accurately predicted sensitivity to small molecule inhibitors and rationally designed combination therapies that synergistically induced cancer cell death.

In most, but not all cases, the functional oncogene signatures accurately predicted increased sensitivity to
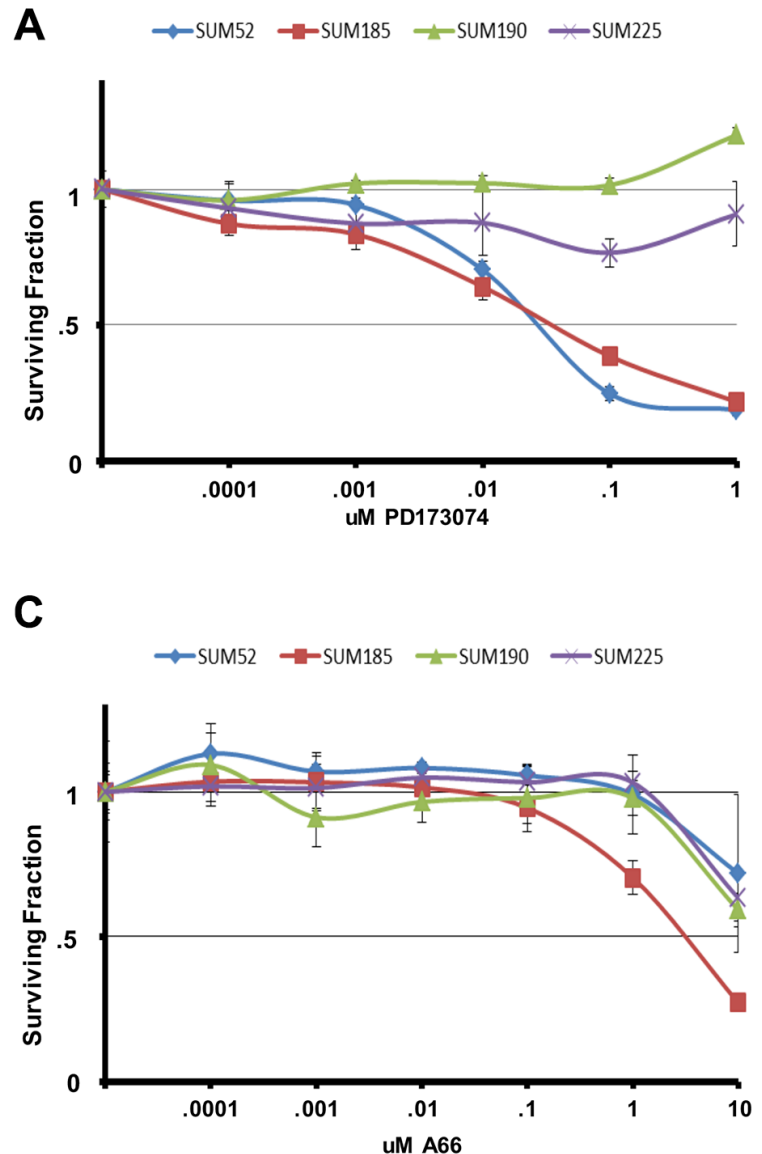

drugs that target functional oncogenes. Thus, the SUM52 and SUM-185 signatures contain FGFR2 and FGFR3 respectively and these cells are exquisitely sensitive to the small molecule FGFR inhibitor PD173074. Similarly, SUM-185 cells, which have a PIK3CA mutation were most sensitive to the PI3'K inhibitor A66. SUM-225 cells, with HER2 (and GRB7) in the oncogene signature were highly sensitive to the HER2 specific drug CP274174. Interestingly, SUM-190 cells also have a HER2 amplification and over-expression, but neither HER2 nor GRB7 were hits in the screen, and thus neither gene is part of the SUM-190 functional oncogene signature. SUM190 cells, while responsive to the HER2 inhibitor, were 10-fold more resistant than SUM-225 cells. SUM-190 cells also harbor an activating PIK3CA mutation and, surprisingly, were no more sensitive to PI3'K inhibitors than other cell lines without PIK3CA mutations. Also, in that regard, CDK6 amplification was not predictive of increased sensitivity to palbociclib.

Among the novel breast cancer oncogenes identified in this study was the anti-apoptotic protein BCL2L1. BCL2L1 plays a role in promoting survival in several solid tumor types [45-48] and has been recently implicated as an amplified driver oncogene in colorectal cancer and

B

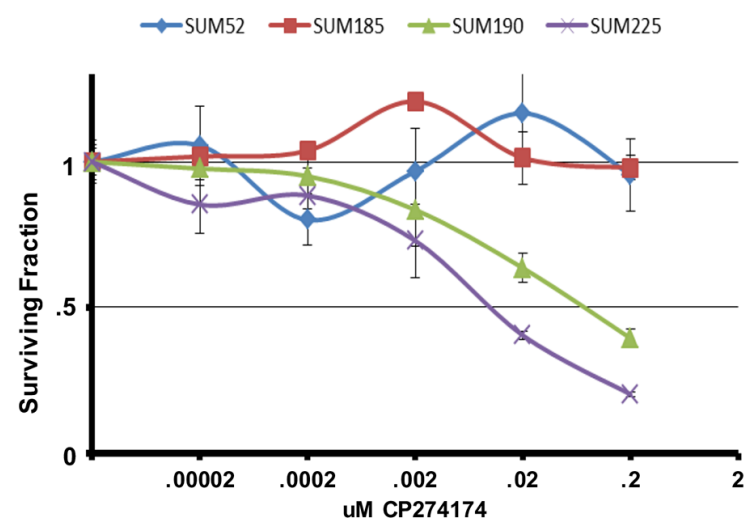

D

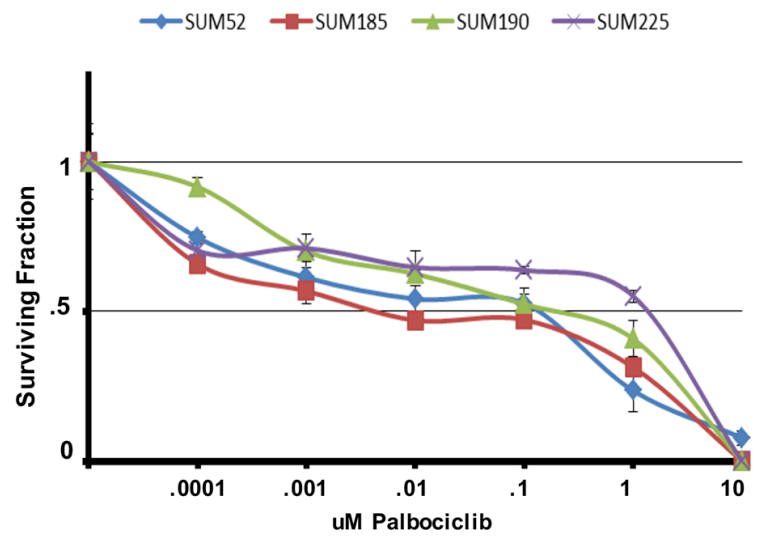

Figure 2: Oncogene signatures predict sensitivity to molecularly targeted drugs. Cell number for each cell line in the panel following exposure to the indicated concentrations of (A) PD173074 (B) CP724714 (C) A66 or (D) Palbociclib for 96 hours. Cell number is shown as the fraction of control treated cells. 
gastric cancer [18, 49-51]. Small molecules that bind to and inhibit the anti-apoptotic function of BCL2L1 and the related BCL2 protein have been developed and are currently in phase I/II clinical trials. In our study, we observed that BCL2L1 was amplified and over-expressed in the SUM-185 cell line and was also a strong hit in the functional genetic screen (5th ranked gene out of 1266 hits). Growth assay experiments showed that SUM185 cells were highly sensitive to the BCL2L1 inhibitor Navitoclax, which is consistent with a role for BCL2L1 as a driver oncogene in this cell line. We also identified an additional breast cancer cell line with amplification and over-expression of BCL2L1 and showed that this cell line was similarly sensitive to BCL2L1 inhibition. Data from the TCGA database indicates that a significant portion of breast cancers harbor amplification and/or overexpression of BCL2L1. These results suggest that BCL2L1 is a driver oncogene in a subset of breast cancers and that those patients with BCL2L1 as part of their oncogene signature may benefit from therapies targeting BCL2L1.
We also found that when multiple oncogenes in the oncogene signature were targeted, cells were not only inhibited in their proliferation, but their clonogenic capacity was dramatically reduced. This was particularly true when a drug that targeted a driving oncogene that resulted in down-regulation of AKT-phosphorylation was combined with inhibition of BCL2L1. In a previous study, we demonstrated that amplified FGFR2 and mutant PIK3CA were linked to AKT phosphorylation in SUM185 cells, and that targeting either oncogene alone induced potent inhibition of cell proliferation. However, this growth inhibition was reversible as indicated by small decreases in clonogenic capacity following drug removal [44]. By contrast, simultaneous inhibition of FGFR2 and BCL2L1, or PIK3CA and BCL2L1 in SUM-185 cells resulted in dramatic reductions in clonogenic survival. Interestingly, targeting BCL2L1 alone at concentrations that inhibited cell proliferation had only marginal effects on clonogenic capacity. This result suggests that AKT activity can support cell survival in the presence of
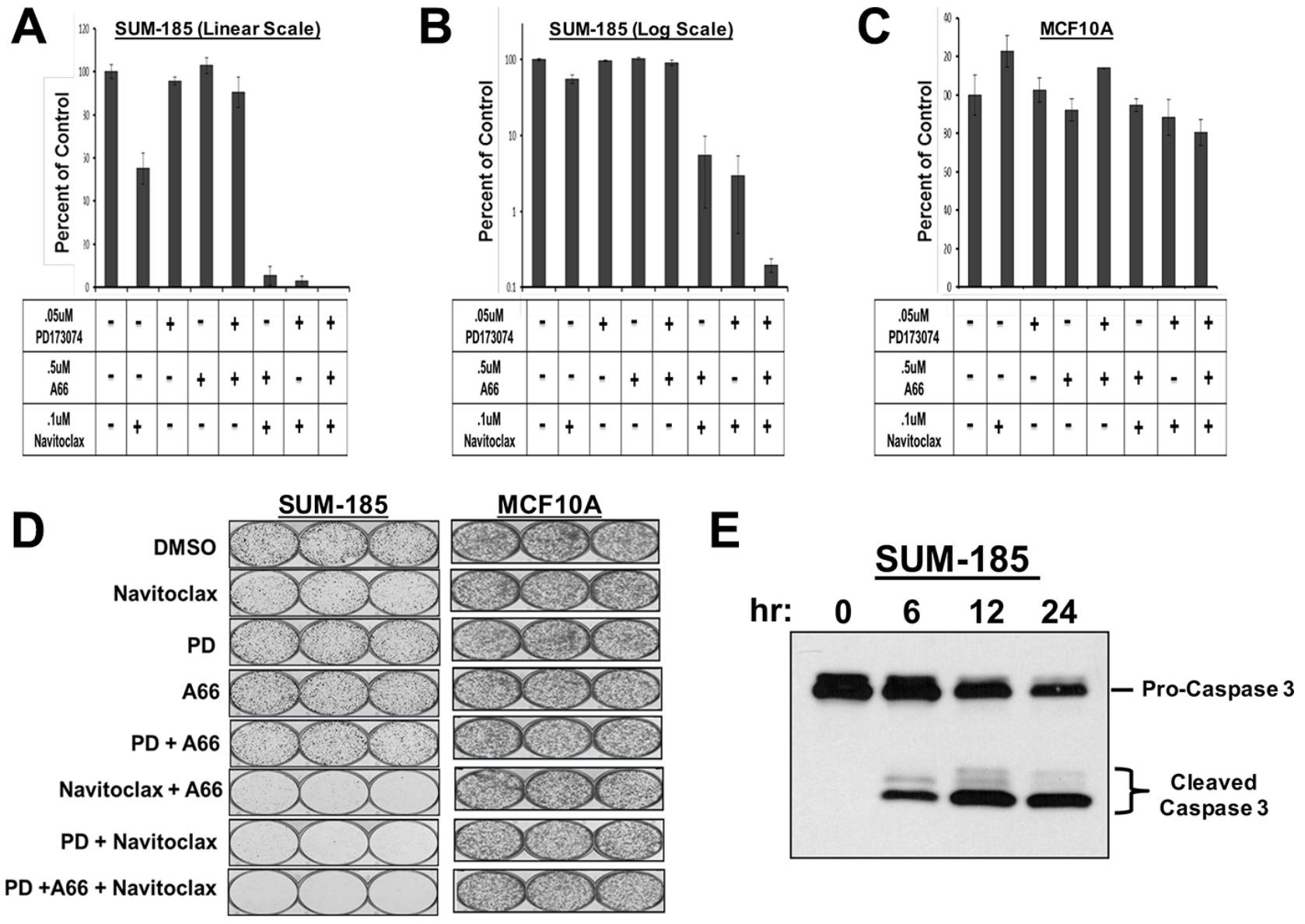

Figure 3: Oncogene signatures guide rational combination therapies that synergistically induce cancer cell death. (A) Clonogenic survival results for SUM-185 cells treated with the indicated small molecule inhibitors for 72 hours. Colonies were stained and counted when colony sizes reached 50-100 cells per colony. Colony counts were normalized to DMSO treated cells. (B) Data from panel A plotted on a semi-log scale. (C) Clonogenic survival assay results for MCF10A cells treated with the indicated small molecule inhibitors. Colony counts were normalized to DMSO treated cells. (D) Images of colony forming assays shown in panels (A-C). (E) Western blot analysis of Caspase 3 following treatment of SUM-185 cells for 6, 12, or 24 hours with the three drug combination of .05 uM PD173074, $.5 \mathrm{uM}$ A66 and .1 uM Navitoclax. 


\section{A}

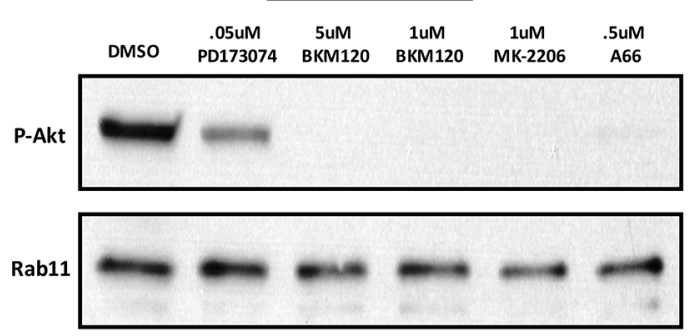

C

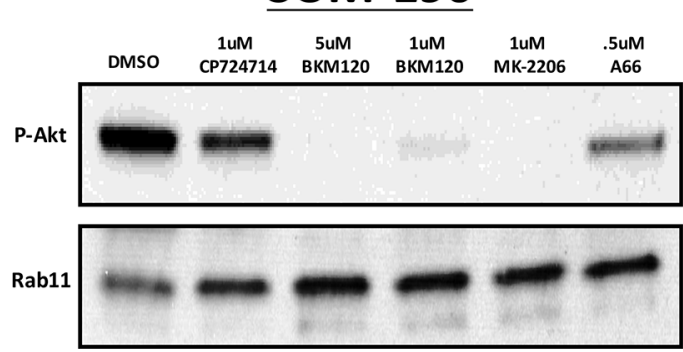

B

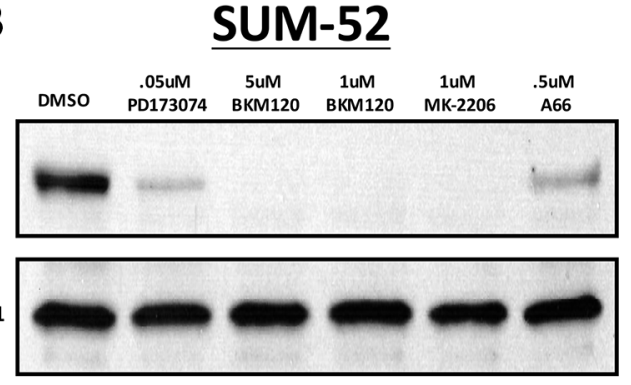

D

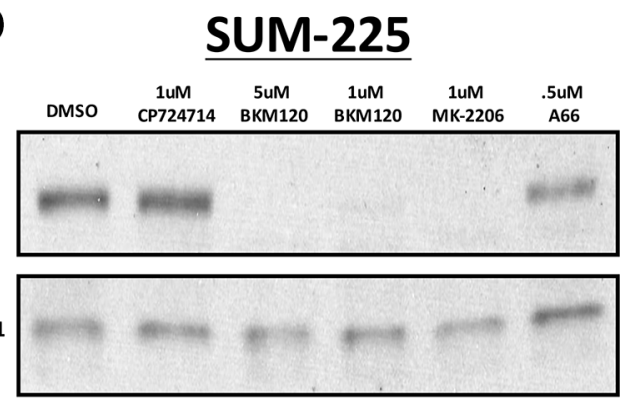

Figure 4: Identification of small molecule inhibitors that inhibit AKT phosphorylation in each of the cell lines in the panel. Western blot analysis of phospho-AKT (Ser473) protein levels following treatment with the indicated small molecule inhibitors in (A) SUM-185 (B) SUM-52 (C) SUM-190 or (D) SUM-225 cells. Western blot analysis of Rab11 protein levels served as a protein loading control.
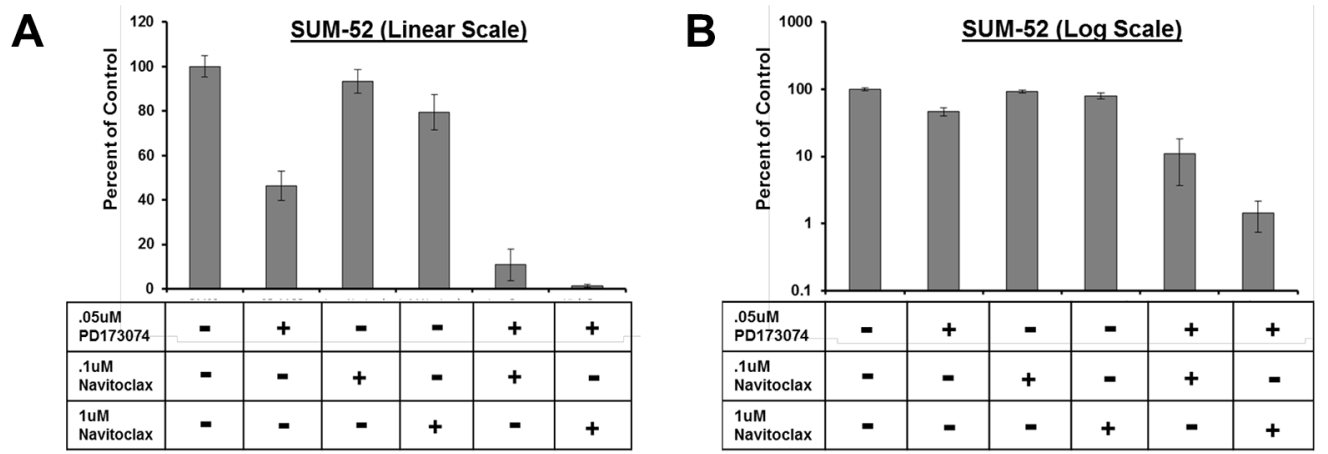

C

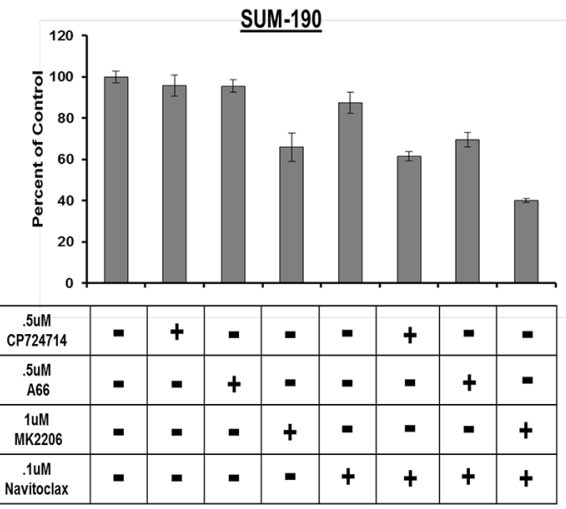

D

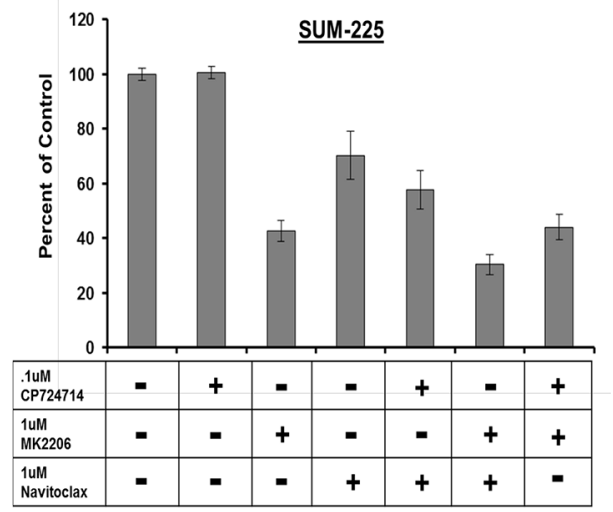

Figure 5: Combination treatment strategy targeting BCL2L1 activity and AKT phosphorylation in multiple breast cancer cell lines. Clonogenic survival analysis for (A) SUM-52 (B) SUM-52 plotted on a semi-log scale (C) SUM-190 or (D) SUM-225. Cells were treated with the indicated small molecule inhibitors for 72 hours. Colonies were stained and counted when colony sizes reached 50-100 cells per colony. Colony counts were normalized to control treated cells. 
BCL2L1 inhibition, and vice versa, but that simultaneous inhibition of both oncogenes results in profound and irreversible loss of proliferative capacity. Extending this result to SUM-52 cells which do not harbor BCL2L1 amplification but in which BCL2L1 was a hit in the shRNA screen, we found that we could induce synergistic loss of clonogenic capacity by combining the FGFR inhibitor with Navitoclax, but because BCL2L1 was not part of the oncogene signature in these cells, higher concentrations of drug were required to achieve a strong effect. Finally, combined inhibition of BCL2L1 activity and AKT phosphorylation did not result in synergistic effects in either the SUM-190 or SUM-225 cell lines, which is consistent with the failure of BCL2L1 to be a hit in the shRNA screen in these cell lines. Synergistic responses are therefore cell type-specific and depend on the addiction of the breast cancer cells to the targeted functional oncogenes.

Recently, Engelman et al. performed a genome-wide screen to identify genes that, when inhibited, cooperate with MEK inhibitors to kill KRAS mutant cancer cells [52]. The top hit identified in this screen was BCL2L1. Grant et al. [53] also observed potent synergy from combining BCL2L1 inhibitors with inhibition of AKT in leukemias and have suggested this as a strategy to treat AML. Taken together, these results and ours provide strong rationale for the development of combination therapies that target BCL2L1 and AKT, particularly in light of the observed synergy which allows for the use of very low doses of the targeted drugs.

AKT is an important protein that regulates, among other things, cell survival, and is considered a potential therapeutic target. However, given the importance of AKT activity in many cellular pathways, targeting AKT directly is often associated with significant side effects. Thus, it is preferable, from a therapeutic standpoint, to inactivate AKT indirectly by targeting the oncogene that is responsible for its activity. This approach will allow cancer cell-specific inactivation of AKT, which is vital to obtaining a high therapeutic index. Our results demonstrate that functional oncogene signatures can identify driver oncogenes that are responsible for driving AKT signaling and in turn allow for rational targeting of AKT through these drivers.

A personalized medicine approach for cancer treatment holds the promise of treating patients with highly effective targeted therapeutics that are tailored to the genetic alterations that drive their cancer. Realizing this promise will require accurate identification of the complete set of oncogenes to which each patient's cancer cells are addicted. Understanding the complete set of activated oncogenes that drive a patients' tumor will allow for rationally designed combination therapies that induce profound decreases in clonogenic survival with minimal effects on normal cells and tissues.

\section{MATERIALS AND METHODS}

\section{Reagents and cell lines}

All inhibitors were purchased from Selleckchem. The PathScan ${ }^{\circledR}$ (\#5301) and Caspase-3(\#9665) antibodies were purchased from Cell Signaling. The SUM breast cancer cell lines were maintained as described previously $[14,54,55]$. MCF10A cells were a gift from Dr. Herb Soule at the Michigan Cancer Foundation [56].

\section{Array comparative genomic hybridization}

Microarrays with an average resolution of $35 \mathrm{~kb}$ (Agilent Human Genome CGH Microarray 44k chip) were hybridized after direct labeling of DNA with fluorescent dyes. DNA extraction was performed using standard column purification (Qiagen) and normal human female DNA was used as the reference. Dye-reversed replicates were performed. Regions of chromosomal amplification and deletion were determined based on circular binary segmentation provided by the Bioconductor DNA copy library.

\section{Genome-scale RNAi-based growth and viability screen}

Virus pools expressing shRNA constructs were prepared according to the Cellecta Pooled Lentiviral shRNA Libraries User Manual protocol (www.cellecta. com). HEK 293T cells were transfected with each of the three Cellecta library plasmid DNA pools (Human Modules 1-3) and the Cellecta Ready-to-Use Packaging Mix (Cat \#CPCP-K2A). For each module, virus was titered and used to transduce $5 \times 10^{\wedge} 7$ target cells at an MOI of $\sim .5$ in the presence of $5 \mathrm{ug} / \mathrm{ml}$ polybrene. Following transduction, cells were cultured for 3 days to allow expression of the resistance marker and nontransduced cells were eliminated from the culture by addition of the selective agent puromycin to the growth media at $6 \mathrm{ug} / \mathrm{ml}$ for SUM-52 cells or $2 \mathrm{ug} / \mathrm{ml}$ for SUM185, SUM-190, and SUM-225 cells. Three days after the addition of puromycin, cells were trypsinized and one half of the total population was harvested for genomic DNA preparation. This DNA served as the reference time point DNA. The remaining cells were plated and grown for $\sim 5-7$ population doublings before harvesting for genomic DNA preparation. Genomic DNA was prepared by phenol:chloroform extraction according to the Cellecta Pooled Lentiviral shRNA Libraries User Manual protocol.

Barcode sequences were amplified from genomic DNA by two rounds of PCR. For first round PCR, 50-100 $\mu \mathrm{g}$ of genomic DNA was used for $4 \times 100 \mu \mathrm{l}$ PCR reactions. Each $100 \mu 1$ reaction contained $2 \mu 1$ Titanium Taq polymerase (Clontech Catalog \#639210), 200 nM dNTP mix (Clontech 
Cat\# 639210) and $10 \mu \mathrm{M}$ of each primer (FWDHTS 5'-TTCTCTGGCAAGCAAAAGACGGCATA-3' and RevHTS1 5'-TAGCCAACGCATCGCACAAGCCA-3'). First round PCR reactions began with activation of the polymerase by incubation at $94^{\circ} \mathrm{C}$ for 3 minutes followed by 16 cycles of denaturation at $94^{\circ} \mathrm{C}$ for $30 \mathrm{sec}$, annealing at $65^{\circ} \mathrm{C}$ for $10 \mathrm{sec}$, and elongation at $72^{\circ} \mathrm{C}$ for $20 \mathrm{sec}$. Final extension was performed by incubation at $68^{\circ} \mathrm{C}$ for 2 minutes. First round PCR reactions were pooled and $100 \mu \mathrm{l}$ was used to seed a $4 \times 100 \mu 1$ second round PCR reaction. Each $100 \mu$ second round reaction contained $2 \mu \mathrm{l}$ Titanium Taq polymerase, $200 \mathrm{nM}$ dNTP mix and $10 \mu \mathrm{M}$ of each primer (FWDGEX 5'-CAAGCAGAAGACGGCATACGAGA-3' and RevGEX 5'-AATGATACGGCGACCACCGAGA-3'). Second round PCR reactions began with activation of the polymerase by incubation at $94^{\circ} \mathrm{C}$ for 3 minutes followed by 12 to 16 cycles of denaturat'ion at $94^{\circ} \mathrm{C}$ for $30 \mathrm{sec}$, annealing at $65^{\circ} \mathrm{C}$ for 10 sec, and elongation at $72^{\circ} \mathrm{C}$ for $10 \mathrm{sec}$. Final extension was performed by incubation at $68^{\circ} \mathrm{C}$ for 2 minutes.

Amplified barcode sequences were run on a $3.5 \%$ agarose gel and purified using a QIAquick Gel Extraction Kit (Qiagen) according to manufacturer's instructions. Isolated barcode sequences were further purified using the PureLink Quick PCR Purification Kit (Invitrogen) according to the manufacturer's instructions. For sequencing, purified barcodes were diluted to $.75 \mathrm{ng} / \mu \mathrm{l}$ using buffer EB (Qiagen). Amplicons were clustered at $17 \mathrm{pM}$ including 30\% (v/v) PhiX to add sequence diversity. Single end (SE) clustering was performed on a Cbot according to the manufacturer's protocol (Illumina, San Diego, CA). A total of 36 cycles of SE sequencing were performed on an Illumina HiScanSQ. Custom primer GexSeqS (5' AGAGGTTCAGAGTTCTACAGTCCGAA-3'， HPLC Purified) was added to the Illumina sequencing primers at $0.5 \mu \mathrm{M}$. Fastq files were generated using CASAVA 1.8.2 and processed using Trimmomatic software (www. usadellab.org) to trim read lengths to 18 nucleotides. Trimmed reads were deconvoluted using Cellecta Barcode Analyzer and Deconvoluter software. Fold depletion scores for each shRNA were calculated as the ratio of the read count at the reference time point versus the final time point.

In the Cellecta shRNA library, the vast majority of genes were targeted by either $5(67 \%)$ or 6 different shRNAs (32\%), and a small fraction of genes (1\%) were targeted by 2 to 69 different shRNAs. The genes targeted by large numbers of shRNAs were housekeeping genes that would be expected to be hits in most, if not all, cell lines tested. Luciferase, which was used as the nonsilencing control was also targeted by over 60 shRNAs and helped to establish the range of scores for known negative hits. Because of the varying numbers of shRNAs per gene, simply ranking hits based on the 2nd highest score or on a weighted average of the top two genes would have biased analysis towards genes with a larger number of shRNAs per gene. To account for this potential bias, log-transformed depletion scores and a quantile estimation approach in which the 80th percentile for each gene was calculated from its empirical distribution were used. This avoided the bias induced by the varying number of scores per gene and accounted for the skewness of the empirical distributions. Genes were then ranked by this log-quantile score and the empirical distribution of the log-quantile score was calculated.

To generate a null distribution of log fold-depletion scores, it was assumed that the majority of genes $(>95 \%)$ would not be depleted, and their log-quantile scores would have a normal distribution. Based on this assumption, the median of the empirical distribution was used as an estimate of the mean of the null distribution. The estimate of the standard deviation of the null distribution was defined as the 97.5th quantile minus the 2.5th quantile, divided by 4 . This was based on the knowledge that $95 \%$ of the data in a normally distributed variable falls between $+/-$ two standard deviations from the mean. Using this null distribution, all genes having log-fold depletion scores that were larger than the 95th percentile of the null distribution were identified as 'hits'. Using this method, all genes that were hits in the screen had at least two, and usually more, shRNAs with depletion scores above the cut-point.

\section{Exome sequencing}

Exome sequencing of SUM cell line DNA was performed essentially as described previously [57]. Briefly, Agilent Sure Select XT reagents were used to prepare sequencing libraries. Hybrid capture was performed using Agilent Sure SelectXT Human All Exon V4+UTRs, and 100 bp paired-end sequencing was performed on a HighSeq2000.

\section{Small molecule inhibitor dose response assays}

Cells were plated in 24-well plates at a density of $15-30,000$ cells per well. Cells were allowed to recover for 4 days before being treated in triplicate with the indicated inhibitors or DMSO control every 24 hours for 4 days. On the 5 th day cell number was determined by harvesting and counting nuclei on a Z1 Coulter Counter (Beckman Coulter, Brea, CA, USA). To prepare nuclei for counting, cells were washed three times with PBS, incubated on a rocker table with $0.5 \mathrm{ml}$ per well Hepes/ $\mathrm{MgCl}_{2}$ buffer (0.01 mM HEPES and $0.015 \mathrm{mM} \mathrm{MgCl}_{2}$ ) for 5 minutes and lysed for 10 minutes with ethyl hexadecyldimethylammonium solution.

\section{Clonogenic survival assays}

Cells were seeded at clonal density in triplicate in 6-well plates and treated with the indicated small 
molecule inhibitors at 24 and 48 hours after plating. At 72 hours cells were washed and cultured in normal growth media until colony sizes reached $\sim 50-100$ cells. For staining, colonies were fixed with $1 \mathrm{~mL} /$ well $3.7 \%$ paraformaldehyde for $20 \mathrm{~min}$ at RT. Colonies were stained with $1 \mathrm{~mL} /$ well $0.2 \%$ crystal violet for 15 minutes at RT and de-stained with $\mathrm{dH} 2 \mathrm{O}$. Colony counts were generated using a GelCount ${ }^{\mathrm{TM}}$ colony counter (Oxford Optronix, Oxfordshire, United Kingdom).

\section{Western blot analysis}

Cells were treated with the indicated concentrations of small molecule inhibitors for 15 hours before preparation of whole cell lysates in RIPA buffer (Sigma Aldrich, R0278) containing $1 \mathrm{mM} \mathrm{Na} \mathrm{VO}_{4}$, and $1 \times$ Protease Inhibitor cocktail (Calbiochem, 539131), and protein concentrations were measured by Bradford assay (Bio-Rad). Equal amounts of protein were combined with Laemmli sample buffer (BioRad, 161-0747), boiled for 5 minutes and separated on SDS polyacrylamide gels (BioRad). Proteins were transferred to polyvinylidene difluoride (PVDF) membranes using the Trans-Blot Turbo System (Bio-Rad) and membranes were probed overnight at $4{ }^{\circ} \mathrm{C}$ with the PathScan ${ }^{\circledR}$ antibody cocktail $(1: 500)$ or Caspase-3 antibody (1:1000).

\section{ACKNOWLEDGMENTS AND FUNDING}

The authors would like to thank Christiana Kappler for editing of the manuscript. This work was supported in part by the Genomics and Biostatistics Shared Resources, Hollings Cancer Center, Medical University of South Carolina (P30 CA138313).

\section{CONFLICT OF INTEREST}

The authors declare no conflicts of interest.

\section{REFERENCES}

1. Weinstein IB, Begemann M, Zhou P, Han EK, Sgambato A, Doki Y, Arber N, Ciaparrone M, Yamamoto H. Disorders in cell circuitry associated with multistage carcinogenesis: exploitable targets for cancer prevention and therapy. Clin Cancer Res. 1997; 3:2696-2702.

2. Weinstein IB. Cancer. Addiction to oncogenes - the Achilles heal of cancer. Science. 2002; 297:63-64.

3. Druker BJ, Sawyers CL, Kantarjian H, Resta DJ, Reese SF, Ford JM, Capdeville R, Talpaz M. Activity of a specific inhibitor of the BCR-ABL tyrosine kinase in the blast crisis of chronic myeloid leukemia and acute lymphoblastic leukemia with the Philadelphia chromosome. N Engl J Med. 2001; 344:1038-1042.

4. Druker BJ, Tamura S, Buchdunger E, Ohno S, Segal GM, Fanning S, Zimmermann J, Lydon NB. Effects of a selective inhibitor of the Abl tyrosine kinase on the growth of BcrAbl positive cells. Nat Med. 1996; 2:561-566.

5. Deininger MW, Druker BJ. Specific targeted therapy of chronic myelogenous leukemia with imatinib. Pharmacol Rev. 2003; 55:401-423.

6. Druker BJ. Translation of the Philadelphia chromosome into therapy for CML. Blood. 2008; 112:4808-4817.

7. Esteva FJ, Yu D, Hung MC, Hortobagyi GN. Molecular predictors of response to trastuzumab and lapatinib in breast cancer. Nat Rev Clin Oncol. 2010; 7:98-107.

8. Cobleigh MA, Vogel CL, Tripathy D, Robert NJ, Scholl S, Fehrenbacher L, Wolter JM, Paton V, Shak S, Lieberman G, Slamon DJ. Multinational study of the efficacy and safety of humanized anti-HER2 monoclonal antibody in women who have HER2-overexpressing metastatic breast cancer that has progressed after chemotherapy for metastatic disease. J Clin Oncol. 1999; 17:2639-2648.

9. Slamon DJ, Leyland-Jones B, Shak S, Fuchs H, Paton V, Bajamonde A, Fleming T, Eiermann W, Wolter J, Pegram M, Baselga J, Norton L. Use of chemotherapy plus a monoclonal antibody against HER2 for metastatic breast cancer that overexpresses HER2. N Engl J Med. 2001; 344:783-792.

10. Cataldo VD, Gibbons DL, Perez-Soler R, QuintasCardama A. Treatment of non-small-cell lung cancer with erlotinib or gefitinib. N Engl J Med. 2011; 364:947-955.

11. Vultur A, Villanueva J, Herlyn M. Targeting BRAF in advanced melanoma: a first step toward manageable disease. Clin Cancer Res. 2011; 17:1658-1663.

12. Forozan F, Veldman R, Ammerman CA, Parsa NZ, Kallioniemi A, Kallioniemi O, Ethier SP. Molecular cytogenetic analysis of 11 new human breast cancer cell lines. Br J Cancer. 1999; 81:1328-1334.

13. Tannheimer SL, Rehemtulla A, Ethier SP. Characterization of fibroblast growth factor receptor 2 overexpression in the human breast cancer cell line SUM-52PE. Breast Cancer Res. 2000; 2:311-320.

14. Forozan F, Veldman R, Ammerman CA, Parsa NZ, Kallioniemi A, Kallioniemi OP, Ethier SP. Molecular cytogenetic analysis of 11 new breast cancer cell lines. Br J Cancer. 1999; 81:1328-1334.

15. Koboldt DC, Zhang Q, Larson DE, Shen D, McLellan MD, Lin L, Miller CA, Mardis ER, Ding L, Wilson RK. VarScan 2: somatic mutation and copy number alteration discovery in cancer by exome sequencing. Genome Res. 2012; 22:568-576.

16. Kappler CS, Guest ST, Irish JC, Garrett-Mayer E, Kratche Z, Wilson RC, Ethier SP. Oncogenic signaling in amphiregulin and EGFR-expressing PTEN-null human breast cancer. Mol Oncol. 2015; 9:527-543.

17. Turner-Ivey B, Guest ST, Irish JC, Kappler CS, GarrettMayer E, Wilson RC, Ethier SP. KAT6A, a chromatin modifier from the 8p11-p12 amplicon is a candidate oncogene in luminal breast cancer. Neoplasia. 2014; 16:644-655. 
18. Beroukhim R, Mermel CH, Porter D, Wei G, Raychaudhuri S, Donovan J, Barretina J, Boehm JS, Dobson J, Urashima M, Mc Henry KT, Pinchback RM, Ligon $\mathrm{AH}$, et al. The landscape of somatic copy-number alteration across human cancers. Nature. 2010; 463: 899-905.

19. Mermel CH, Schumacher SE, Hill B, Meyerson ML, Beroukhim R, Getz G. GISTIC2.0 facilitates sensitive and confident localization of the targets of focal somatic copy-number alteration in human cancers. Genome biology. 2011; 12:R41.

20. Forbes SA, Beare D, Gunasekaran P, Leung K, Bindal N, Boutselakis H, Ding M, Bamford S, Cole C, Ward S, Kok CY, Jia M, De T, et al. COSMIC: exploring the world's knowledge of somatic mutations in human cancer. Nucleic Acids Res. 2015; 43:D805-811.

21. Samuels Y, Wang Z, Bardelli A, Silliman N, Ptak J, Szabo S, Yan H, Gazdar A, Powell SM, Riggins GJ, Willson JK, Markowitz S, Kinzler KW, et al. High frequency of mutations of the PIK3CA gene in human cancers. Science. 2004; 304:554.

22. Campbell IG, Russell SE, Choong DY, Montgomery KG, Ciavarella ML, Hooi CS, Cristiano BE, Pearson RB, Phillips WA. Mutation of the PIK3CA gene in ovarian and breast cancer. Cancer Res. 2004; 64:7678-7681.

23. Stephens PJ, Tarpey PS, Davies H, Van Loo P, Greenman C, Wedge DC, Nik-Zainal S, Martin S, Varela I, Bignell GR, Yates LR, Papaemmanuil E, Beare D, et al. The landscape of cancer genes and mutational processes in breast cancer. Nature. 2012; 486:400-404.

24. Cancer Genome Atlas N. Comprehensive molecular portraits of human breast tumours. Nature. 2012; 490: $61-70$.

25. Kang S, Bader AG, Vogt PK. Phosphatidylinositol 3-kinase mutations identified in human cancer are oncogenic. Proc Natl Acad Sci U S A 2005; 102:802-807.

26. Bachman KE, Argani P, Samuels Y, Silliman N, Ptak J, Szabo S, Konishi H, Karakas B, Blair BG, Lin C, Peters BA, Velculescu VE, Park BH. The PIK3CA gene is mutated with high frequency in human breast cancers. Cancer Biol Ther. 2004; 3:772-775.

27. Tse C, Shoemaker AR, Adickes J, Anderson MG, Chen J, Jin S, Johnson EF, Marsh KC, Mitten MJ, Nimmer P, Roberts L, Tahir SK, Xiao Y, et al. ABT-263: a potent and orally bioavailable Bcl-2 family inhibitor. Cancer Res. 2008; 68:3421-3428.

28. Moffa AB, Tannheimer SL, Ethier SP. Transforming potential of alternatively spliced variants of fibroblast growth factor receptor 2 in human mammary epithelial cells. Mol Cancer Res. 2004; 2:643-652.

29. Yang ZQ, Moffa AB, Haddad R, Streicher KL, Ethier SP. Transforming properties of TC-1 in human breast cancer: Interaction with FGFR2 and beta-catenin signaling pathways. Int J Cancer. 2007; 121:1265-1273.
30. Andre F, Bachelot T, Campone M, Dalenc F, PerezGarcia JM, Hurvitz SA, Turner N, Rugo H, Smith JW, Deudon S, Shi M, Zhang Y, Kay A, et al. Targeting FGFR with dovitinib (TKI258): preclinical and clinical data in breast cancer. Clin Cancer Res. 2013; 19:3693-3702.

31. Mohammadi M, Froum S, Hamby JM, Schroeder MC, Panek RL, Lu GH, Eliseenkova AV, Green D, Schlessinger J, Hubbard SR. Crystal structure of an angiogenesis inhibitor bound to the FGF receptor tyrosine kinase domain. EMBO J. 1998; 17:5896-5904.

32. Jani JP, Finn RS, Campbell M, Coleman KG, Connell RD, Currier N, Emerson EO, Floyd E, Harriman S, Kath JC, Morris J, Moyer JD, Pustilnik LR, et al. Discovery and pharmacologic characterization of CP-724,714, a selective ErbB2 tyrosine kinase inhibitor. Cancer Res. 2007; 67:9887-9893.

33. Berns K, Horlings HM, Hennessy BT, Madiredjo M, Hijmans EM, Beelen K, Linn SC, Gonzalez-Angulo AM, Stemke-Hale K, Hauptmann M, Beijersbergen RL, Mills GB, van de Vijver MJ, et al. A functional genetic approach identifies the PI3K pathway as a major determinant of trastuzumab resistance in breast cancer. Cancer Cell. 2007; 12:395-402.

34. Fry DW, Harvey PJ, Keller PR, Elliott WL, Meade M, Trachet E, Albassam M, Zheng X, Leopold WR, Pryer NK, Toogood PL. Specific inhibition of cyclin-dependent kinase 4/6 by PD 0332991 and associated antitumor activity in human tumor xenografts. Mol Cancer Ther. 2004; 3: 1427-1438.

35. Misale S, Bozic I, Tong J, Peraza-Penton A, Lallo A, Baldi F, Lin KH, Truini M, Trusolino L, Bertotti A, Di Nicolantonio F, Nowak MA, Zhang L, et al. Vertical suppression of the EGFR pathway prevents onset of resistance in colorectal cancers. Nat Commun. 2015; 6:8305.

36. Bozic I, Reiter JG, Allen B, Antal T, Chatterjee K, Shah P, Moon YS, Yaqubie A, Kelly N, Le DT, Lipson EJ, Chapman PB, Diaz LA Jr, et al. Evolutionary dynamics of cancer in response to targeted combination therapy. Elife. 2013; 2:e0747.

37. Blagosklonny MV. Overcoming limitations of natural anticancer drugs by combining with artificial agents. Trends Pharmacol Sci. 2005; 26:77-81.

38. Swain SM, Baselga J, Kim SB, Ro J, Semiglazov V, Campone M, Ciruelos E, Ferrero JM, Schneeweiss A, Heeson S, Clark E, Ross G, Benyunes MC, et al. Pertuzumab, trastuzumab, and docetaxel in HER2-positive metastatic breast cancer. N Engl J Med. 2015; 372:724-734.

39. Long GV, Weber JS, Infante JR, Kim KB, Daud A, Gonzalez R, Sosman JA, Hamid O, Schuchter L, Cebon J, Kefford RF, Lawrence D, Kudchadkar R, et al. Overall Survival and Durable Responses in Patients With BRAF V600-Mutant Metastatic Melanoma Receiving Dabrafenib Combined With Trametinib. J Clin Oncol. 2016; 34:871-878. 
40. Long GV, Stroyakovskiy D, Gogas H, Levchenko E, de Braud F, Larkin J, Garbe C, Jouary T, Hauschild A, Grob JJ, Chiarion Sileni V, Lebbe C, Mandala M, et al. Combined BRAF and MEK inhibition versus BRAF inhibition alone in melanoma. N Engl J Med. 2014; 371:1877-1888.

41. Robert C, Karaszewska B, Schachter J, Rutkowski P, Mackiewicz A, Stroiakovski D, Lichinitser M, Dummer R, Grange F, Mortier L, Chiarion-Sileni V, Drucis K, Krajsova I, et al. Improved overall survival in melanoma with combined dabrafenib and trametinib. N Engl J Med. $2015 ; 372: 30-39$.

42. Blagosklonny MV. Matching targets for selective cancer therapy. Drug Discov Today. 2003; 8:1104-1107.

43. Rao GS, Murray S, Ethier SP. Radiosensitization of human breast cancer cells by a novel ErbB family receptor tyrosine kinase inhibitor. Int J Radiat Oncol Biol Phys. 2000; 48:1519-1528.

44. Guest ST, Kratche ZR, Bollig-Fischer A, Haddad R, Ethier SP. Two members of the TRiC chaperonin complex, CCT2 and TCP1 are essential for survival of breast cancer cells and are linked to driving oncogenes. Exp Cell Res. 2015; 332:223-235.

45. Lam LT, Zhang H, Chyla B. Biomarkers of therapeutic response to BCL2 antagonists in cancer. Mol Diagn Ther. 2012; 16:347-356.

46. Amundson SA, Myers TG, Scudiero D, Kitada S, Reed JC, Fornace AJ Jr. An informatics approach identifying markers of chemosensitivity in human cancer cell lines. Cancer Res. 2000; 60:6101-6110.

47. Yu X, Yang L, Cairns MJ, Dass C, Saravolac E, Li X, Sun LQ. Chemosensitization of solid tumors by inhibition of Bcl-xL expression using DNAzyme. Oncotarget. 2014; 5:9039-9048. doi: 10.18632/oncotarget.1996.

48. Chen J, Jin S, Abraham V, Huang X, Liu B, Mitten MJ, Nimmer P, Lin X, Smith M, Shen Y, Shoemaker AR, Tahir SK, Zhang $\mathrm{H}$, et al. The Bcl-2/Bcl-X(L)/ Bcl-w inhibitor, navitoclax, enhances the activity of chemotherapeutic agents in vitro and in vivo. Mol Cancer Ther. 2011; 10:2340-2349.

49. Sillars-Hardebol AH, Carvalho B, Belien JA, de Wit M, Delis-van Diemen PM, Tijssen M, van de Wiel MA, Ponten F, Fijneman RJ, Meijer GA. BCL2L1 has a functional role in colorectal cancer and its protein expression is associated with chromosome $20 \mathrm{q}$ gain. J Pathol. 2012; 226:442-450.
50. Zhang H, Xue J, Hessler P, Tahir SK, Chen J, Jin S, Souers AJ, Leverson JD, Lam LT. Genomic analysis and selective small molecule inhibition identifies BCL-X(L) as a critical survival factor in a subset of colorectal cancer. Mol Cancer. 2015; 14:126.

51. Park H, Cho SY, Kim H, Na D, Han JY, Chae J, Park C, Park OK, Min S, Kang J, Choi B, Min J, Kwon JY, et al. Genomic alterations in BCL2L1 and DLC1 contribute to drug sensitivity in gastric cancer. Proc Natl Acad Sci U S A. $2015 ; 112: 12492-12497$.

52. Corcoran RB, Cheng KA, Hata AN, Faber AC, Ebi H, Coffee EM, Greninger P, Brown RD, Godfrey JT, Cohoon TJ, Song Y, Lifshits E, Hung KE, et al. Synthetic lethal interaction of combined BCL-XL and MEK inhibition promotes tumor regressions in KRAS mutant cancer models. Cancer cell. 2013; 23:121-128.

53. Vachhani $\mathrm{P}$, Bose $\mathrm{P}$, Rahmani $\mathrm{M}$, Grant S. Rational combination of dual PI3K/mTOR blockade and Bcl-2/-xL inhibition in AML. Physiol Genomics. 2014; 46:448-456.

54. Ethier SP, Mahacek ML, Gullick WJ, Frank TS and Weber BL. Differential isolation of normal luminal mammary epithelial cells and breast cancer cells from primary and metastatic sites using selective media. Cancer Res. 1993; 53:627-635.

55. Ethier SP. Human breast cancer cell lines as models of growth regulation and disease progression. J Mammary Gland Biol Neoplasia. 1996; 1:111-121.

56. Tait L, Soule HD, Russo J. Ultrastructural and immunocytochemical characterization of an immortalized human breast epithelial cell line, MCF-10. Cancer Res. 1990; 50:6087-6094.

57. Butler TM, Johnson-Camacho K, Peto M, Wang NJ, Macey TA, Korkola JE, Koppie TM, Corless CL, Gray JW, Spellman PT. Exome Sequencing of Cell-Free DNA from Metastatic Cancer Patients Identifies Clinically Actionable Mutations Distinct from Primary Disease. PLoS One. 2015; 10:e0136407. 